\title{
Does Confucianism promote cooperation and integration in East Asia?
}

\author{
Katarzyna Anna Nawrot ${ }^{1}$ (D)
}

Received: 8 October 2019 / Revised: 28 January 2020 / Accepted: 5 February 2020 /

Published online: 17 February 2020

(C) The Author(s) 2020

\begin{abstract}
This paper examines the commonality of culture in East Asia and its relationship with economic cooperation and the integration of the region, and shows how Confucian ethics and philosophy have played a significant role in the economic growth and development of the various countries there. It finds, however, that there is still insufficient recognition of Confucian and Asian values as the potential mainstay of a regional identity on which economic integration can be built and enhanced. The earliest catalysts of cooperation and integration in East Asia were political and security threats. Later, functional integration was accomplished through globalization and market forces. Yet the institutionalization of the processes is inevitable and necessary if cooperation and integration are to be deepened and strengthened. This can be achieved by building a regional identity. Thus, cultural community based on Confucianism can serve as a pillar of regional common identity and values as a necessary condition to consolidate and integrate East Asian countries into a single economic community.
\end{abstract}

Keywords Confucianism $\cdot$ Cultural system $\cdot$ Economic cooperation and integration · East Asia

\section{Introduction}

The late twentieth century and early twenty-first century have seen impressive economic growth and development in the countries of East Asia, which has enabled the individual countries and the region itself to move into the spotlight of the global

Katarzyna Anna Nawrot

nawrotini@gmail.com

1 Polish Academy of Sciences, Committee of Future Studies "Poland 2000 Plus", Warsaw, Poland 
economy. The scale of income growth and poverty reduction achieved in the region, which is reflected in the standard of living, life expectancy and human development of its countries, is unprecedented in the history of mankind. Economic cooperation and integration in East Asia has played an important role by creating a specific model of the division of labour, cooperation and economic integration. It has also promoted peace and progress by contributing to the welfare of its countries and societies. Cooperation and integration in East Asia reflects the regional and global importance of the individual economies, their economic potential, their population, and their political systems.

Culture and its components are often omitted in analyses of cooperation and integration. We attempt to rectify this by assessing the role of Confucianism, which is a very important element of the cultural system, in the cooperation and integration of East Asia. Within the geographical scope of the analysis 15 countries and territories of East Asia are considered, namely: China, Japan, South Korea, Hong Kong and Taiwan-defined as Northeast Asia and Brunei Darussalam, Cambodia, Indonesia, Laos, Malaysia, Myanmar, Philippines, Singapore, Thailand and Vietnam-specified as Southeast Asian countries. The paper briefly evaluates the economic potential of East Asia and then offers an overview of the nature and evolution of cooperation and integration in the region. This includes the history and background of cooperation and integration in East Asia, the institutional interdependence of the region, functional integration, and the regional division of labour connectivity. This section ends with an assessment of the level and effectiveness of inter-country integration based on selected economic measures. Next we identify norms and values which derive from Confucianism and refer to the literature to discuss how they might promote cooperation and integration between societies. There follows a review of Confucianism as an element of the cultural system in East Asian economic development and of cooperation and integration in East Asia. Conclusions are then drawn and the paper ends by recommending broader recognition of Confucianism as a pillar of the region's common identity and as a necessary condition for the consolidation and integration of its countries in a single economic community.

\section{The economic potential of East Asia}

East Asia's economic transformation was begun in the 1960s by Japan: the oldest of the Asian tigers. The group of newly-industrialized countries was then joined by South Korea, Hong Kong, Taiwan, and Singapore in the 1970s, and later by Malaysia, Thailand, and Indonesia from Southeast Asia. From that point onwards, other countries from the region began to imitate their model of industrialisation, which they did by developing their industrial production, opening their economies to international competition and shifting away from the policy of import substitution in favor of an export-oriented strategy. Simultaneously, they enjoyed rapid economic growth and development. The group of emerging markets was later joined by China and Vietnam and, in recent years, by the Philippines. Table 1 illustrates the economic potential of the individual countries of the region. 


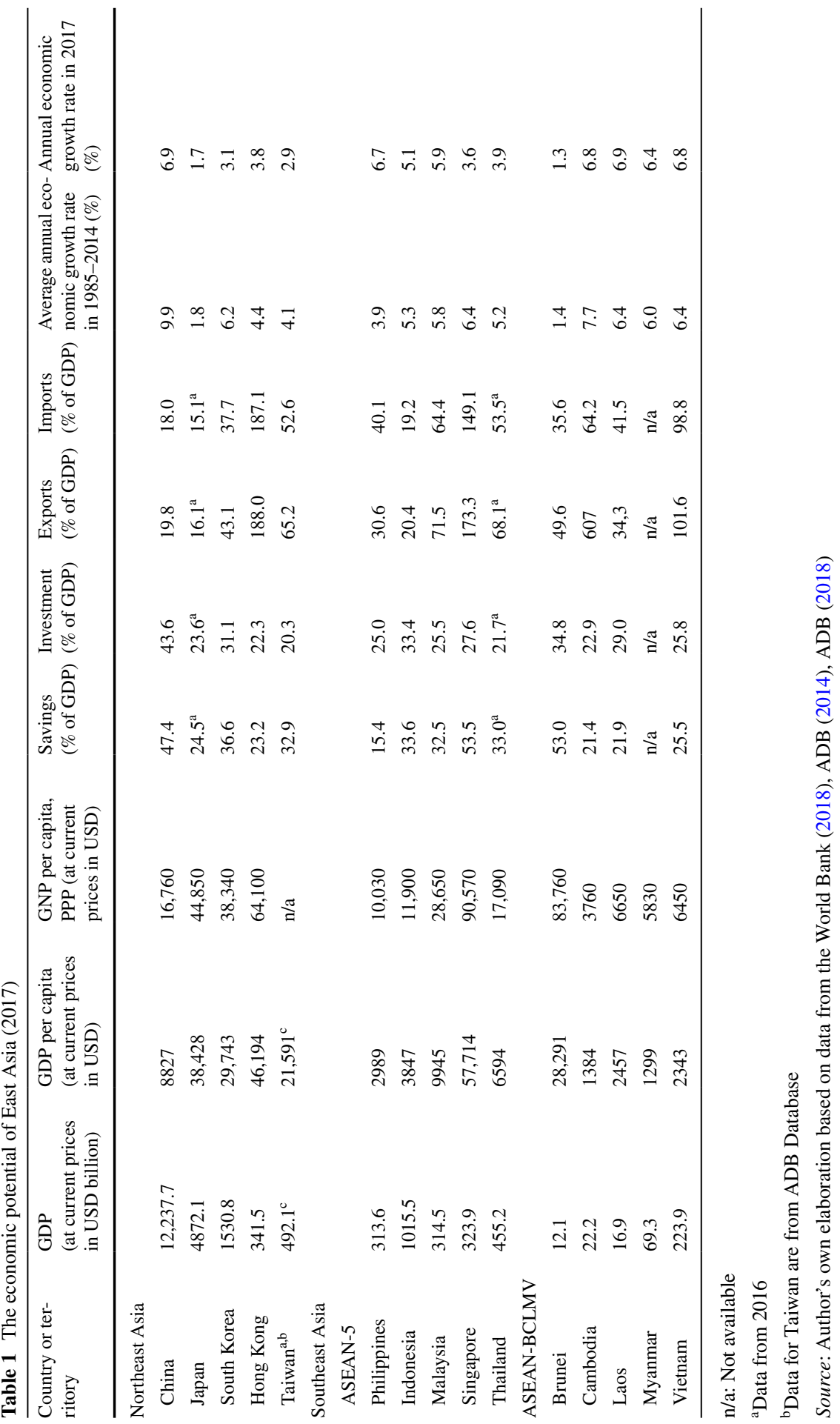




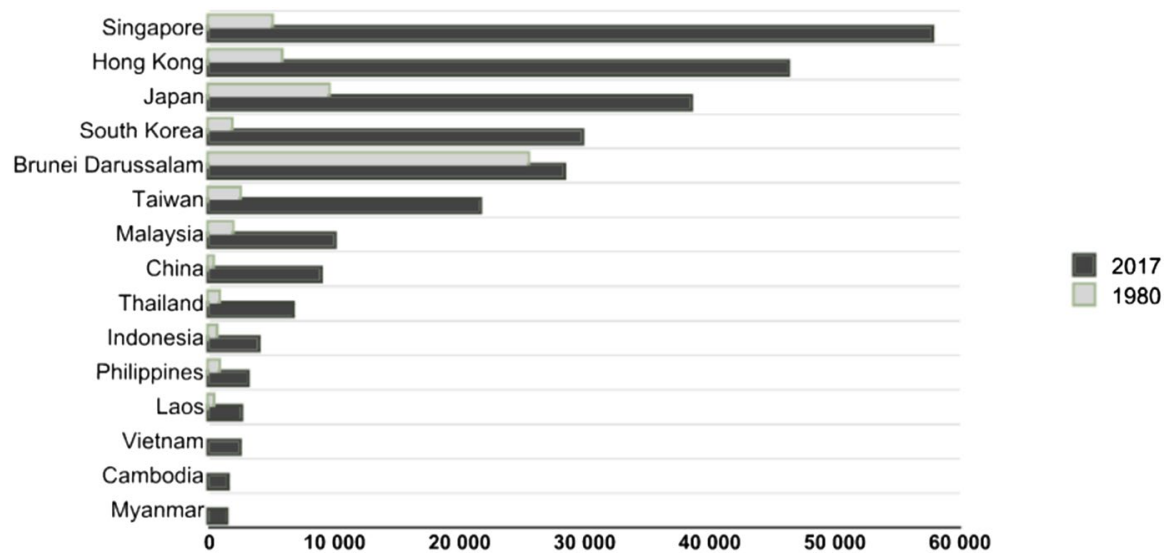

Fig. 1 GDP per capita in East Asia in 1980 and 2017 (current prices; USD). Source: Author's own elaboration based based on World Bank data (2018)

In recent years, the pace of economic growth recorded in the developing countries in Asia has been twice the global average, and far greater than that in developed countries and other developing regions (IMF 2013; Nawrot 2014, pp. 83-84). In 1985-2014, the average annual rate of economic growth exceeded $8 \%$ in the developing countries of East Asia and the Pacific and hovered around 5\% for the region as a whole (World Bank 2018). GDP grew fastest in 1985-2014 in China, where average annual growth was approximately $10 \%$, while the majority of the economies reported an average annual economic growth rate of more than 5\% (Table 1). Many countries overcame the economic slowdown triggered by the Asian financial crisis in the 1990s and made a successful return to rapid growth. The financial crisis that swept the globe in the first decade of the twenty-first century was also not without its influence on the region's countries. Yet analyses have found that this slump was more severe in developed and developing countries in South America, the Caribbean, Central and Eastern Europe and the euro zone than in the Asian markets. The reasons lie in the macroeconomic fundamentals of the region's countries when the crisis emerged and in the results of the corrective measures they took individually and collectively in response to the financial crisis of the 1990s, which meant that the East Asian countries were less vulnerable when the financial crisis of 2008-2009 struck (see Nawrot 2013, pp. 280-281).

It is important to state that the positive effects of economic growth have given rise to increased levels of income, a reduction in poverty, and better health and education. Indeed, when the years 1980 and 2017 are compared, all of the region's countries reported growth in income and GDP per capita. The latter rose particularly swiftly in China, South Korea, Singapore, Vietnam and Thailand (Fig. 1).

In both regional and global terms, industrialization and economic advancement have shifted the economic and political position, and status, of the region's countries, which nevertheless remain greatly diverse with regard to 


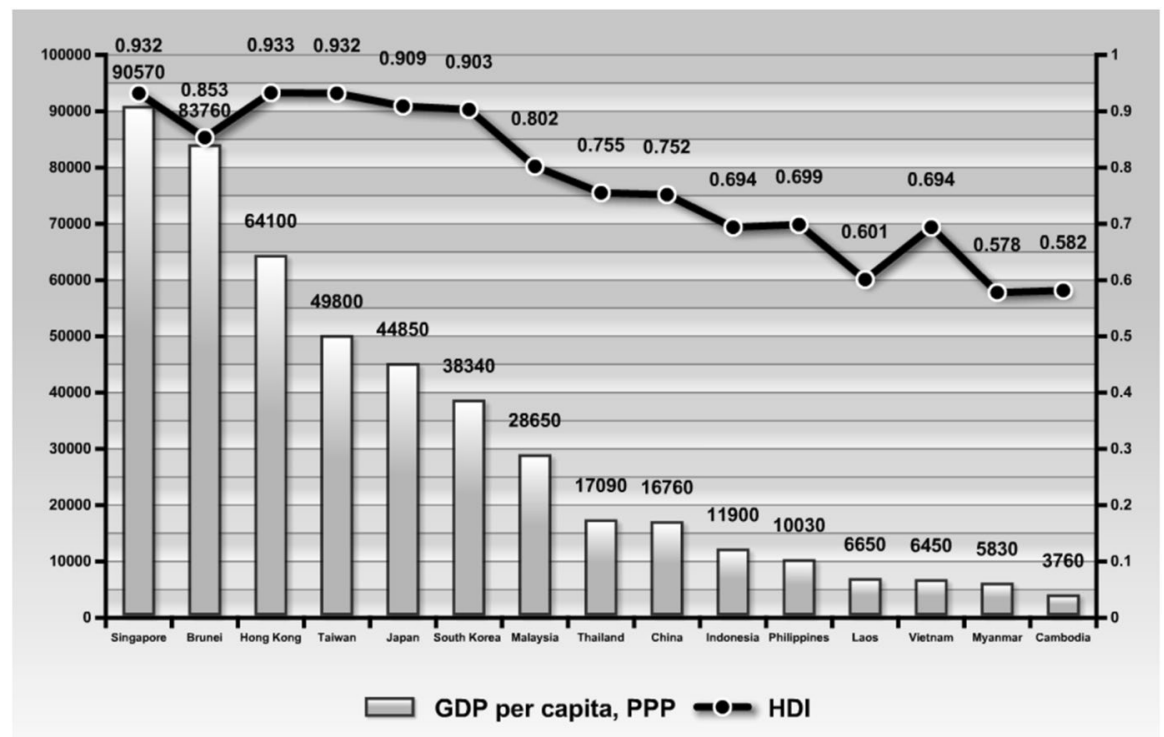

Fig. 2 GDP per capita, PPP and HDI in East Asia in 2017 (current prices; USD). Source: Author's own elaboration based on World Bank data (2018) and UNDP (2018)

culture, ideology, politics, economics and history. Japan has been by far the most advanced economy followed by the newly industrialized economies of South Korea, Hong Kong, Taiwan and Singapore, the remaining ASEAN-5 countries, China and Vietnam, and the remaining countries of Indochina (ASEAN-CML). Japan has of course now been joined by China as a regional power and together they have taken the leading role in the region's economic performance and, as a consequence, also in regional cooperation and integration.

Following three decades of concentrated economic growth and development, the individual economies can be classified as falling into almost all income groups. The high-income economies are Japan, Singapore, Brunei, Hong Kong, Taiwan and South Korea, the upper-middle-income countries are Malaysia, China, Thailand and Indonesia, and the lower-middle-income countries are Vietnam, Myanmar, Laos, Cambodia and the Philippines, which make up the largest group. Finally, the poorest countries of East Asia are Myanmar, Cambodia, Laos and Vietnam (see World Bank 2018). If we compare GDP per capita at purchasing power parity with human development measured on the human development index (HDI), we discover considerable disparities between the countries of East Asia. This is displayed in Fig. 2. 


\section{Overview of the nature and evolution of cooperation and integration in East Asia}

\section{The history of cooperation and integration in East Asia}

East Asia, which is a diverse, multidimensional region, has never had an integrationist tradition in the way Europe has. The colonial period further deepened inter-country disparities and even built upon some of the barriers and antagonisms. As Kim argues (1998, pp. 32-33, after Kang 2004, p. 115), the name 'East Asia' itself began to gain traction as a result of the dynamic economic growth shown in particular countries of the region since the 1970s. Until then, the region had been just a geographic concept used and defined mainly by the Europeans. The discovery of the sea route to the East at the turn of the fifteenth century and sixteenth century saw the beginning of European colonial expansion in East Asia and the concurrent popularization of the term 'Asia' to denote the continent and its sub-regions. A variety of explanations of the word 'Asia' can be found in the literature. It is stated that it originates from the Euro-Mediterranean cultural circle. In Assyrian, asu meant east, while in Greek 'Asian' referred to the Persian empire and meant 'foreign' or 'hostile' (Haliżak 1999, p. 51; Grabowski 2015, p. 75). In the many senses in which the meaning of Asian values were disseminated, 'Asian' also defines the culture and civilization of East Asian societies (Haliżak 1999, p. 52). Historically, though, it is far harder to ground an Asian identity than it is to ground the identities of the great Chinese, Korean, Vietnamese, Khmer, Mongolian or Tibetan civilizations that originated in the region.

Decolonisation, decline of the ideological doctrine of the Cold War period and the economic rise of East Asian countries restored the Asian consciousness and identity. Simultaneously, the beginning of cooperation in the region could be mark along with the decolonisation processes, when numerous integration initiatives were undertaken. The first notable initiatives were the establishment of SEATO (South-East Asia Treaty Organization) in 1954, of ASA (Association of Southeast Asia) in 1961, of ASPAC (Asian and Pacific Council) in 1966 and of Maphilindo (Malaya, Philippines and Indonesia) in 1963. These initiatives reflected the divergent goals and expectations of the parties involved and were also influenced by territorial disputes and the bi-polar divisions of the world after World War II.

The region's countries were nevertheless aware of the necessity and inevitability of dialogue and cooperation-especially in the face of the external threats that arose after decolonisation from attempts by the colonial powers to maintain the status quo in the region. Military threats and ideological consequences arising from the Cold War were also smouldering. Further stimuli for strengthening the position, independence and self-governance of the region in the international arena were provided by the increasing political power of China and by Japan's economic expansion. Hence the Association of Southeast Asian Nations (ASEAN) was established with the signing of the Bangkok Declaration on 8 August 1967 by the foreign ministers of five Southeast Asian countries: 
Indonesia, Malaysia, Philippines, Singapore and Thailand. Other Southeast Asian countries were invited to join but declined, largely for political reasons, to do so.

ASEAN was founded on principles of regional cooperation, which in the main meant regional economic cooperation. When stating them, the founders held up the European Economic Community as an example (Khoman 1992; Rajaratnam 1992). Yet the economic goals that ASEAN first adopted could not take priority until the 1980s and 1990s because of the region's political predicament: the situation in Indochina, the war in Vietnam and various issues in Cambodia (Nawrot 2008, p. 78). Since 1967 when it was formed, ASEAN's five founder members have been joined by Brunei Darussalam (1984), Vietnam (1995), Laos (1997), Myanmar (1997), and Cambodia (1999) and it now includes all of the countries of Southeast Asia. East Timor, which gained independence in 2002, is expected to become a member in the future.

When compared with the European model, integration and cooperation in Southeast Asia and East Asia was not perceived as an especially institutional matter (Welfens et al. 2006). Instead, it was implied that the success of the 'ASEAN way' in regional integration policy lay in a relatively open policy of 'soft balancing' that involved little interference (Tellis et al. 2011). Furthermore, attempts to institutionalise cooperation in the region, which included implementation of the ASEAN Charter in 2007, were perceived as a threat as well as an opportunity to integrate more deeply (Singh and Than 2008). Although external threats may well have driven the preliminary stages of integration, the importance for regional cooperation should be further attributed to regional institutions. At the early nineties the intensification of institutional approaches was observed. Notable in this respect were the measures taken by ASEAN to boost integration and secure closer cooperation among the region's countries - in the first place integration initiatives among the Association of Southeast Asian Nations, what was supposed to boost the integration processes and tighten the cooperation among the countries from the region. This could be understood as a response to globalisation, but it has also been inherent in integration processes undertaken by the EU (European Union) and NAFTA (North American Free Trade Agreement) and in the emergence of the economies of China and India. The Asian financial crisis of 1997-1998 was pivotal for constructing regional identity, strengthening the mechanisms of regional cooperation and deepening integration between the countries of East Asia.

The inability to act together to prevent the crisis and the absence of mechanisms enabling a rapid response demonstrated the importance of joint institutions and prompted a number of initiatives. One of the first came in 1997 when an informal meeting of the leaders of ASEAN, China, Japan, and South Korea launched the ASEAN + format during the ASEAN Summit in Malaysia (Wu 2010, p. 331). It took institutional form two years later at the ASEAN Summit in Manila, which set the Joint Statement on East Asia Cooperation in motion, and was consolidated by the Second Joint Statement on East Asia Cooperation and by the ASEAN + 3 Cooperation Work Plan (2007-2017).

Countries began to cooperate in the financial sector to provide stability and protection in case of a financial meltdown and, in the aftermath of the crisis, Japan proposed that member states of the Asian Development Bank (ADB) establish an 
Asian Monetary Fund (AMF). Its purpose was to deepen economic and, especially, monetary integration in the region. In this, Japan, due to its economic potential and the nature of its relations with the United States, was to take the lead ( $\mathrm{Su} 2010$, pp. 28-29), but instead withdrew and signed the Chiang Mai Initiative of 2002, which provided for a network of bilateral swap agreements worth USD 80 billion and was signed by all of the ASEAN + 3 economies. The ASEAN + 3 dialogue enabled the implementation of the Chiang Mai Initiative and the later Chiang Mai Initiative Multilateralization (CMIM), as well as the establishment of the ASEAN + 3 Macroeconomic Research Office (Buckley et al. 2011). In the light of earlier decades, this represented concerted and purposeful action designed to secure closer cooperation and partnership. More than this, it inaugurated further institutional measures in support of cooperation and integration in East Asia, which are the subject of the next section of the paper.

\section{Institutional interdependence in East Asia}

Extensive cooperation and integration has gradually spread beyond Southeast Asia and ASEAN to other countries from East Asia, and has even extended beyond the region to the intercontinental level (ADB 2010; Frost 2008; Fujita et al. 2011). This growing institutional interdependence has taken the form of multilateral and bilateral structures of cooperation, which gave rise both to East Asian community building and to what is known as the Asian-noodle-bowl effect or the Asian-spaghettibowl effect-a notion that has been widely discussed by scholars such as Baldwin, Kim, Nawrot, Park, Pempel and Thornton (Baldwin and Thornton 2008; Nawrot 2007; Park et al. 2011). In Asia and the Pacific alone, we have witnessed a surge in Free Trade Agreements (FTAs): four were concluded in 1990, 39 in 2000, 110 in 2010 and 158 in 2019. If we include FTAs currently in negotiation we reach an impressive total of 253 (ARIC; August 2019). Bilateral and multilateral cooperation is in progress as well with countries from outside the region and at the intercontinental level. Table 2 illustrates the growing interdependence of trade agreements in East Asia.

There are various forms that existing free trade agreements take, and that potential free trade agreements might take, in Asia and the Pacific. They include panAsian cooperation agreements, or even broader transpacific cooperation agreements, and range from the East Asian Free Trade Agreement (ASEAN + 3 FTA), through the Comprehensive Economic Partnership Agreement (ASEAN + 6 FTA), to the Asia-Pacific Free Trade Area or the Trans-Pacific Partnership. It should be noted that these were not new ideas. The institutionalisation of cooperation in the region was already under wide discussion in the 1960s when Kiyoshi Kojima, a professor at Japan's Hitotsubahi University, proposed a Pacific Free Trade Area (PAFTA) and, later, an Organization for Pacific Trade and Development (OPTAD), which both failed due to a lack of support from the US (Nawrot 2012, p. 114). The negotiations on the Trans-Pacific Partnership that began in 2010 came to a halt because the United States and Vietnam could not reach agreement on textiles and because 
Table 2 Free trade areas and regional trade arrangements within East Asia (as for May 2018)

\begin{tabular}{|c|c|c|c|c|c|c|c|c|c|c|c|c|c|c|c|c|c|c|}
\hline & 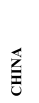 & $\begin{array}{l}z \\
\underline{z} \\
\underline{z}\end{array}$ & 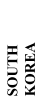 & $\begin{array}{l}0 \\
\vdots \\
\vdots \\
0 \\
z \\
0\end{array}$ & לֶ. & 亲 & 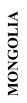 & 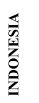 & 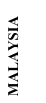 & 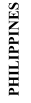 & 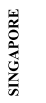 & 菨 & 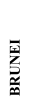 & 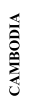 & $\frac{n}{3}$ & 竞 & 公 & $\begin{array}{l}\frac{3}{4} \\
\frac{5}{8}\end{array}$ \\
\hline CHINA & - & - & $\mathrm{X}$ & $\mathrm{X}$ & $\mathrm{X}$ & $\mathrm{X}^{*}$ & 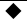 & & & & $\mathrm{X}$ & $\mathrm{X}$ & & & & & & $\mathrm{X}$ \\
\hline JAPAN & $\cdot$ & - & $\bullet$ & & & & $\mathrm{X}$ & $\mathrm{X}$ & $\mathrm{X}$ & $\mathrm{X}$ & $\mathrm{X}$ & $\mathrm{X}$ & $\mathrm{X}$ & & & & $\mathrm{X}$ & $\mathrm{X}$ \\
\hline SOUTH KOREA & $\mathrm{X}$ & - & - & & & & 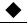 & $\cdot$ & $\bullet$ & & $\mathrm{X}$ & $\diamond$ & & & & & $\mathrm{X}$ & $\mathrm{X}$ \\
\hline HONG KONG & $\mathrm{X}$ & & & - & $\mathrm{X}$ & & & & & & & & & & & & & $\odot$ \\
\hline MACAU & $\mathrm{X}$ & & & $\mathrm{X}$ & - & & & & & & & & & & & & & \\
\hline TAIWAN & $\mathrm{X}^{*}$ & & & & & - & & 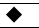 & & 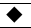 & $\mathrm{X}$ & & & & & & & \\
\hline MONGOLIA & & $\mathrm{X}$ & & & & & - & & & & & & & & & & & \\
\hline INDONESIA & & $\mathrm{X}$ & $\cdot$ & & & $\bullet$ & & - & $\$$ & $*$ & $*$ & $*$ & $\%$ & $*$ & $*$ & $*$ & $\%$ & \\
\hline MALAYSIA & & $\mathrm{X}$ & 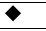 & & & & & $\nLeftarrow$ & - & $*$ & $* \square$ & $\%$ & $* \square$ & $*$ & $*$ & $*$ & $* \square$ & \\
\hline PHILIPPINES & & $\mathrm{X}$ & & & & $>$ & & $*$ & $\%$ & - & $*$ & $\%$ & $*$ & $*$ & $*$ & $*$ & $*$ & \\
\hline SINGAPORE & $\mathrm{X}$ & $\mathrm{X}$ & $\mathrm{X}$ & & & $\mathrm{X}$ & & $*$ & $* \square$ & $*$ & - & $*$ & $\$ \square$ & $*$ & $*$ & $*$ & $* \square$ & \\
\hline THAILAND & $\mathrm{X}$ & $\mathrm{X}$ & 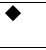 & & & & & $*$ & $*$ & $*$ & $*$ & - & $*$ & $*$ & $\begin{array}{l}* \\
X\end{array}$ & $*$ & $*$ & \\
\hline BRUNEI & & $\mathrm{X}$ & & & & & & $*$ & $\$$ & $*$ & $\begin{array}{l}* \square \\
\square\end{array}$ & $*$ & - & $*$ & $*$ & $*$ & $* \square$ & \\
\hline CAMBODIA & & & & & & & & $*$ & $\%$ & $*$ & $*$ & $\$$ & $*$ & - & $\%$ & $*$ & $*$ & \\
\hline LAOS & & & & & & & & $*$ & 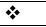 & $*$ & $*$ & $* \mathrm{X}$ & $*$ & $*$ & - & $*$ & $*$ & \\
\hline MYANMAR & & & & & & & & $*$ & $\%$ & $*$ & $*$ & $*$ & $\%$ & $*$ & $*$ & - & $\%$ & \\
\hline VIETNAM & & $\mathrm{X}$ & $\mathrm{X}$ & & & & & $*$ & 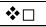 & $*$ & $* \square$ & $*$ & $\%$ & $*$ & $*$ & $*$ & - & \\
\hline ASEAN & $X$ & $\mathrm{X}$ & $\mathrm{X}$ & $\odot$ & & & & - & - & - & - & - & - & - & - & - & - & $\mathrm{X}$ \\
\hline
\end{tabular}

$\mathrm{X}$ : In effect

$\odot$ : Signed but not yet in effect

O : Framework agreement signed

- : Under negotiation

: Proposed/under consultation and study

* : AFTA; ASEAN Free Trade Area

口 : Trans-Pacific Strategic Economic Partnership Agreement

$\square$ : Trans-Pacific Strategic Economic Partnership Agreement-negotiations

*ECFA People's Republic of China-Taipei, China Economic Cooperation Framework Agreement (signed and in effect)

国: Member countries of the D-8 agreement

Source: Author's own elaboration based on ARIC (2018)

there were other issues that could not be resolved. Negotiations were once more suspended in 2017 when the US withdrew.

As Haliżak (2006, p. 140) has observed, the different approaches towards regionalism seem indeed to reflect two alternative concepts of cooperation: the Asia-Pacific basin versus the East Asian community. The latter's distinctive nature was emphasised by the creation of the East Asian Summit (EAS) in 2005. The participation of the US and Russia in the sixth EAS, which was held in November 2011 in Jakarta, and the invitation extended to Brazil to attend the seventh, demonstrated the importance of the East Asia region and the interdependence of countries in the global economy. Numerous recent studies using Computable General Equilibrium (CGE) simulations have shown that greater integration within East Asia, or even within South Asia and East Asia, would be more beneficial than that of the ASEAN countries alone (Kumar et al. 2006). Scientists from the Research and Information System for Developing Countries in New Delhi estimated that ASEAN + 3 would generate welfare gains of USD 162.1 billion and, if India were included, a rise of a further USD 48 billion (ibidem, p. 300). 
These many and varied commitments to integration within East Asia and within Asia and the Pacific suggest that there is no robust political commitment to any of them. It follows that there is no coherent strategy for achieving integration and no political will behind economic integration in East Asia at large. It would appear that the region's countries have been distracted from building a single effective bloc by their involvement in numerous overlapping negotiations. The numerous bilateral disputes, which have dissipated the goodwill and trust needed to build integration, only serve to emphasise the point.

Nevertheless, the growing interdependence of the countries in the region revealed during the Asian financial crisis of 1997-1998 underpinned the necessity of joint strategy and governance at the regional level. What is more, though the crisis raised doubts about the effectiveness of regional institutions, and especially about ASEAN itself, it bolstered regional bonds not just in Southeast Asia but throughout East Asia (Nawrot 2012, p. 34). It seemed that the crisis had taught the East Asian countries the importance of inter-country coordination and governance and that they had digested the lesson that liberalisation should be managed and controlled by governments to ensure that the extent of subordination to foreign markets does not lead to destruction. This is exemplified by the rates of economic growth of the region's countries and by the substantial economic and political shift of East Asian markets in the global economy (Nawrot 2013, p. 279).

\section{Functional integration in East Asia and the regional division of labour connectivity}

Crucial aspect in regional cooperation in East Asia has been the functional or de facto integration associated with international division of labour in the region and the process of industrialization which followed a distinctive model, or paradigm, at least until the mid-1990s. Regional industrial production evolved and so did the lifecycle of the different industries in the various countries. Economies at a lower level of development and industrialization attracted sectors of production from more developed countries where they had become less competitive. Production reallocation was preceded by the acquisition of specialist skills and qualifications. Manufacturers from Japan, followed by those from South Korea, Hong Kong, Taiwan and Singapore, began expanding their business operations in search of more competitive production locations. As a consequence, and particularly in textiles, electronics, and the automotive industry, the region saw the development of production networks, which led to the geographical clustering of enterprises by sector. Furthermore, and especially in infrastructure and finance, growing interdependencies in production processes were coupled with the regionalization of services, which was the result of growing interdependencies between industry and services. We are now witnessing the relocation of production processes from China, Malaysia, and Thailand to the economically less advanced countries of ASEAN-CLMV: Cambodia, Laos, Myanmar and Vietnam. Given China's expanding economy, its rising labour costs and the New Silk Road initiative, we can expect production processes to continue to disintegrate and production to shift to new locations, including the western provinces 


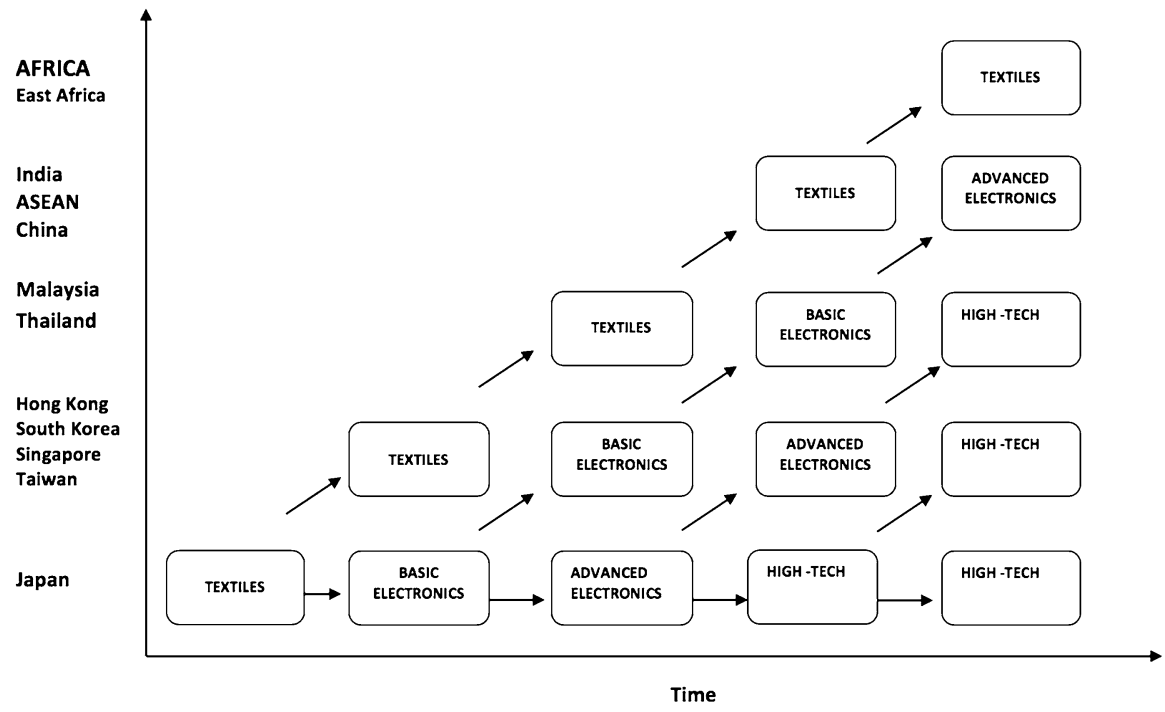

Fig. 3 Characteristics of the international division of labour in East Asia. Source: Nawrot (2018, p. 164)

of China, the countries of Central Asia and, in the long term, perhaps also to the developing African countries (Fig. 3). As a result of the regional division of labour, industrial production has taken place in a variety of locations, which has allowed for specialization at individual stages of the production process and the subsequent export of semi-finished goods for further processing or assembly. This has led to growing fragmentation of production processes and to vertical specialization. Hence on the one hand we have growing production efficiency and on the other diversification of international trade, internationalization and, by the same token, interdependencies not only between the economies of the East Asia region but also within the global market system (Nawrot 2016, p. 360).

Geographic proximity, labour supply, and cultural similarities, which are partly the result of Confucian ethics, are among the factors that have generated the distinctive characteristics of the international division of labour in East Asia and affected the quality of human capital. The heterogeneity of the economies of the region, which has facilitated production segmentation by giving rise to complementarity of production structures and to diversified comparative advantage (see Fig. 3), has also been an important factor. Asia's distinct production processes have acted as a major stimulus to trade. The East Asian economies gained a competitive edge in many industries and therefore increased their share in the global market of industrial goods. In 1985-2013, the countries of East Asia increased their share of global exports of industrial products from 24.1 to $39.6 \%$ and doubled their share of imports (WTO 2015). Most of the countries of the region also reported a growing share of industrial production in total exports. In the mid-1980s, industrial products accounted for over $90 \%$ of exports in Japan, Taiwan and South Korea. Exports of industrial products rose in Singapore, Malaysia, and Thailand in the same period and later did the same in Indonesia, the Philippines and Vietnam. As for China, 
industrialization there was especially dynamic in the late 1980s and early 1990s (World Bank 2015).

In both functional and institutional terms, the regional dimension of integration is a notable aspect of the international division of labour in East Asia because the development of trade and production networks intensified as a result of both institutionalization and market-led forces. Inter-country initiatives for the liberalisation of trade and investment served as an additional catalyst for trade and provided more opportunities for specialization at individual stages of production. Lower costs resulting from reductions in tariff barriers and non-tariff barriers, the development of transportation and communication infrastructure and relative geographic proximity, which lowered transactional costs, all acted as stimuli for the defragmentation of production. This assisted the emergence of platforms or 'oases' for producing semi-finished goods, which were then re-exported for final assembly before being sold, in highly-developed countries for the most part, as finished goods. The model pursued by the Japanese corporations came to be imitated by other multinationals that aimed to benefit from the advantage of location, thus contributing to the expansion of global production networks and growing interdependencies between economies from the region. The evolution of the regional division of labour in East Asia therefore favours the growing fragmentation of production processes in the global sense and, by the same token, the expansion of global value chains. This has been confirmed by Banga (2013), who showed that global value chains had evolved from regional value chains functioning chiefly in East Asia. The expansion of these regional linkages to the whole of Asia was stimulated by Japanese financiers seeking low-cost investment locations in the countries of the region.

As multinational corporations expanded, so did the production networks and clusters created in the region. While this was the outcome of the operation of market forces and institutional processes at the regional level, it was not achieved without states intervening to influence the investment climate and support selected industries and sectors. At first, the countries of East Asia were able to join regional and then global value chains chiefly owing to low labour costs and an ample supply of labour, which smoothed the development of labour-intensive production and low-cost production. The next steps to take would be to increase labour effectiveness, to enlarge the share of the value added by industry in exports under conditions of growing internal consumption, and to boost R\&D spending. This would deliver advanced technology and ensure continued movement up the value chain in the production processes of the region's countries.

Existing sub-regional cooperation in East Asia is another example of how transborder networks, governance and cooperation have given rise to integration. Economic networks, including production networks, have functioned across the different political and economic systems of the countries of East Asia and have stimulated flows of trade and investment. Numerous scholars have stressed the importance of these mechanisms, including the flow of materials, information, people and commodities through the networks of intra-firm, inter-firm and extra-firm relations at the micro level. Further impetus has been generated by technical and managerial integration, financial and trade regulation, ethnic and personal ties, and political mediation, which have resulted in inter-governmental agreements (Cho 1997, p. 1). 
The major mechanisms can be neatly encapsulated as the market and the local community complemented by Asian values and informatization. As an example, Cho (1997) gives the connectivity of China's north-eastern provinces and Korea's central west coast, whose rationale, Cho argues, results from geographical proximity, cultural and ethnic affinity and complementarity of production. Especially interesting is the perception of 'imagined community' as put by Benedict Anderson (2006) or 'the sense of us' as argued by Ricardo Hausmann (2019). The presence of ethnic Korean residents in Northeast China, bond together by 'imaginary spatial identity' or 'the sense of us' was argued by Cho to be the most significant aspect enhancing cross-border interaction between Korea and China, what further transmitted and consolidated Asian values in terms of personal ties and business culture (Cho 1997, pp. 18-19).

\section{The effectiveness of economic integration in East Asia}

Functional economic integration and institutional integration can be identified as two parallel processes in the history of East Asian integration. Yet despite growing institutional interdependence between the region's countries - as already mentioned in earlier part of this paper-no institutional arrangement has yet been agreed for the whole of East Asia. The economic explosion of regional economies ignited by Japan, and now sustained by China, has resulted at the regional level in greater functional integration and division of labour connectivity. We examined three measures to gauge the effectiveness of integration processes: the share of intra-regional trade, ${ }^{1}$ the trade intensity index ${ }^{2}$ and the intra-industry trade index. ${ }^{3}$

If we compare Figs. 4 and 5 we can see that the share of intra-regional trade for ASEAN has been fluctuating between approximately $20 \%$ and $25 \%$ for both exports and imports. Despite the growth in the volume of trade among the ASEAN countries the share has remained at a similar level since the 1990s. If East Asia is taken as a whole, though, the share and volume of intra-regional trade are significantly higher. If we study Figs. 4 and 5 we can see that the share of intra-regional exports for ASEAN + 3 reached approximately 36\% in 2017, when its share of intra-regional imports was $46 \%$. For both ASEAN and ASEAN + 3, the value of intra-regional export intensity and intra-regional import intensity remained above one for the whole period, which indicates functional economic integration and increasing intra-regional trade intensity among the countries. This trend continued

\footnotetext{
1 Intra-Regional Trade Share ${ }_{\mathrm{i}}=\mathrm{T}_{\mathrm{ii}} / \mathrm{T}_{\mathrm{i}}$ where $\mathrm{T}_{\mathrm{ii}}=$ exports of region $i$ to region $i$ plus imports of region $i$ from region $i$, $\mathrm{T}_{\mathrm{i}}=$ total exports of region $i$ to the world plus total imports of region $i$ from the world.

2 Intra-Regional Trade Intensity Index-ITII $I_{i, t}=\frac{\frac{I T_{i, t}}{T_{i, t}}}{\frac{T_{i, t}}{T_{w, t}}}$; where $\mathrm{IT}_{\mathrm{i}, \mathrm{t}}$-intra-regional trade of region $i$ in

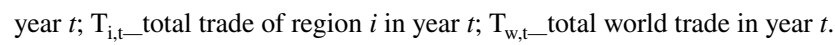

${ }^{3}$ Grubel-Lloyd Intra-industry index-IIT $=\frac{\sum_{i}\left(\sum_{j} X_{i j}+\sum_{j} M_{i j}\right)-\sum_{i}\left|\sum_{j} X_{i j}-\sum_{j} M_{i j}\right|}{\sum_{i}\left(\sum_{j} X_{i j}+\sum_{j} M_{i j}\right)}$; where $X_{i j}$. - exports of commodity $i$ with country $j ; M_{i j}$-imports of commodity $i$ with country $j$.
} 
Exports

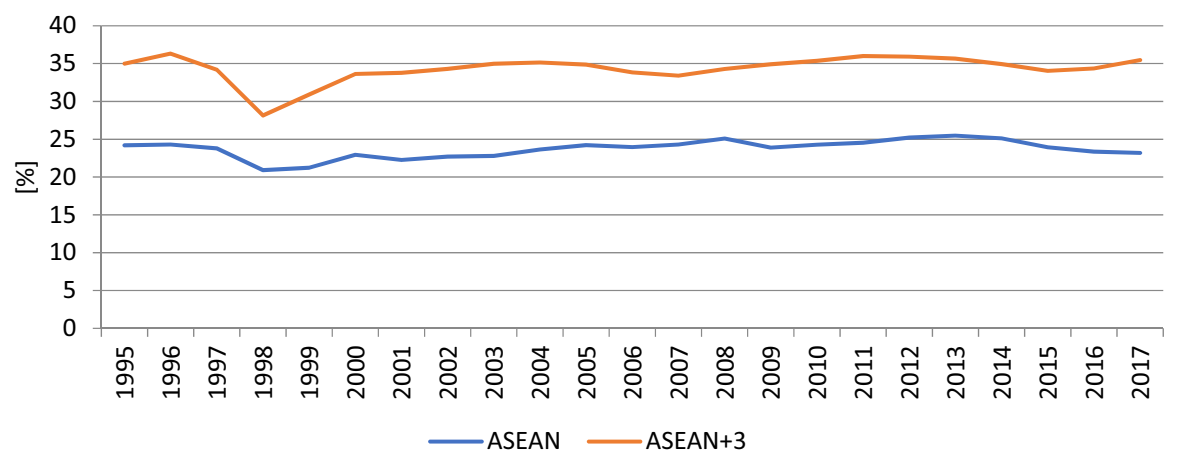

Fig. 4 Intra-regional exports of ASEAN and ASEAN + 3 in 1995-2017 (\%). Source: Author's own calculations based on UNCTAD Database (2019)

Imports

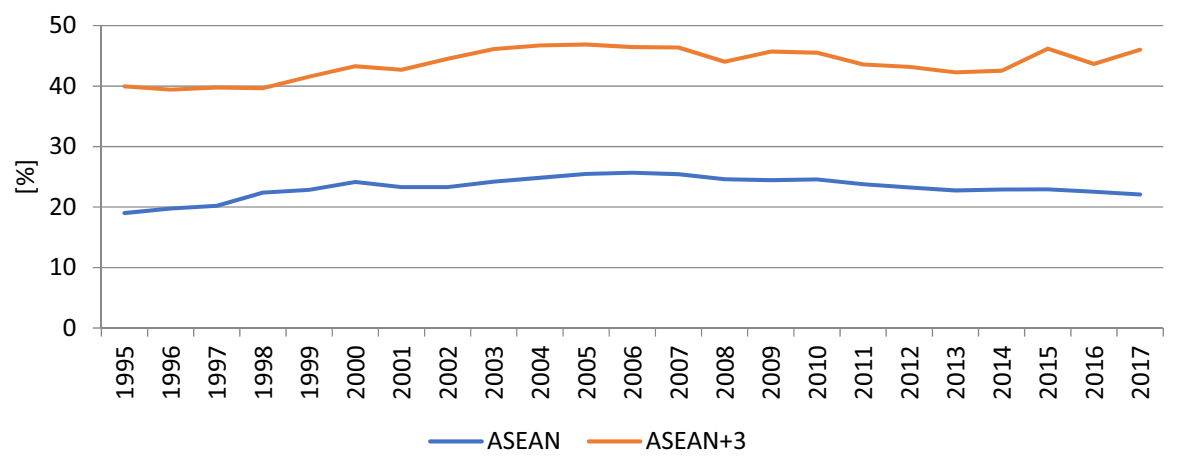

Fig. 5 Intra-regional imports of ASEAN and ASEAN + 3 in 1995-2017 (\%). Source: Author's own calculations based on UNCTAD Database (2019)

until the 2007-2008 financial crisis (compare Tables 3, 4 and Fig. 6). Despite the decline in both intra-regional import intensity and intra-regional export intensity the indexes remain high and are above the world average, which offers evidence for functional integration of the region's countries. The same can be said of the GrubelLloyd intra-industry trade indexes for all of the countries of East Asia in respect of ASEAN, ASEAN + 3 and the entire region of East Asia (see Figs. 7, 8, 9).

Though functional integration among the East Asian countries is largely accomplished, their institutional integration continues to be obstructed by historical issues (especially sensitive in the Japan-China-Korea nexus) and by economic, political, historical and cultural disparities (economic development, economic and political systems, ideology, culture, historical burdens, emotional distrust), remains incomplete. Functional integration and the market-oriented economic interdependency of the region's trading partners are therefore clearly the driving forces, that is to say, functional integration through market forces leads to institutional integration more 


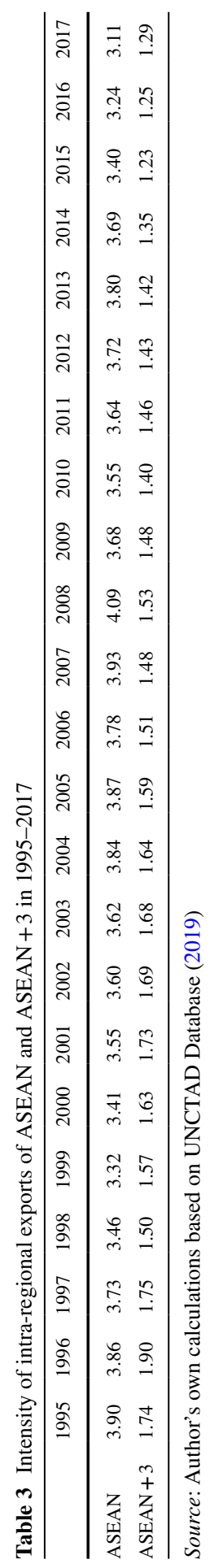




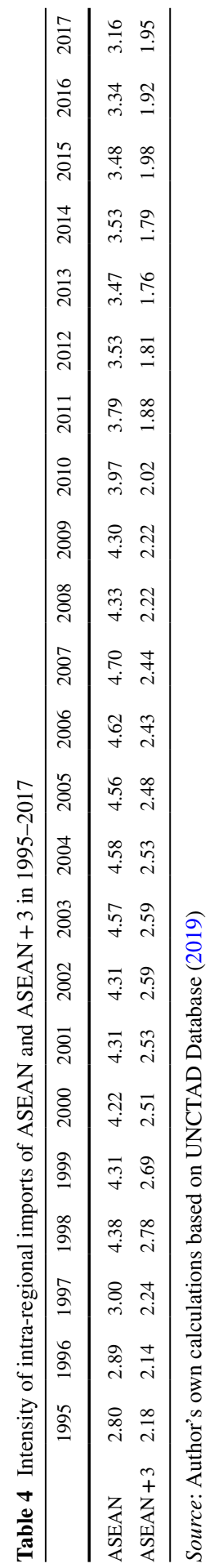




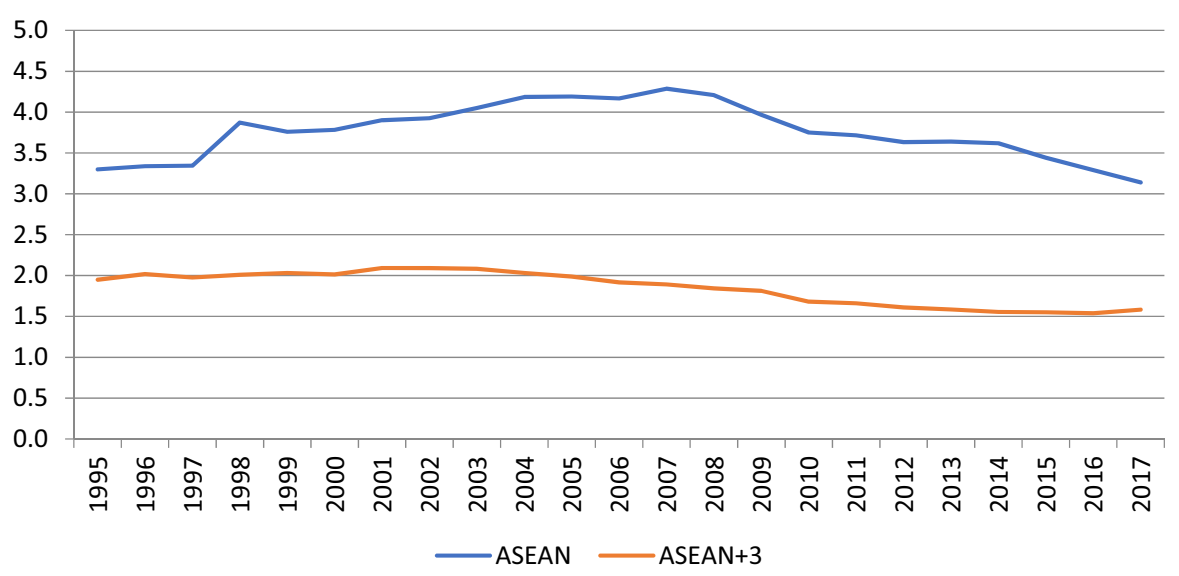

Fig. 6 Intensity of intra-regional trade of ASEAN and ASEAN + 3 in 1995-2017. Source: Author's own calculations based on UNCTAD Database (2019)

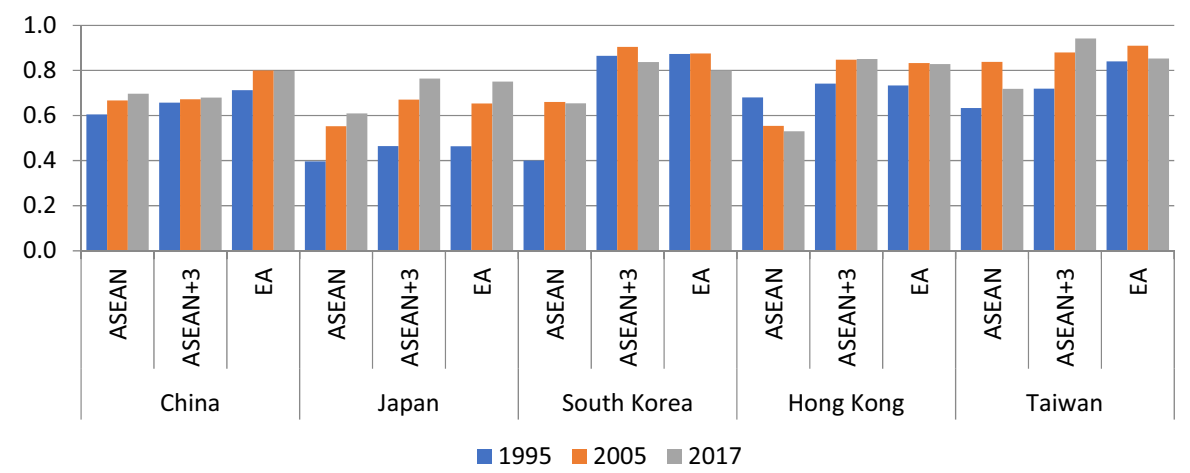

Fig. 7 Grubel-Lloyd intra-industry trade indexes: Northeast Asia in respect of ASEAN, ASEAN +3 and East Asia in 1995, 2005, 2017. Source: Author's own calculations based on UNCTAD Database (2019)

often than institutional integration leading to functional integration. In the East Asian case the effects of trade creation have also exceeded the effects of trade diversion, which is partly because functional integration was already established, as is shown by intra-regional trade, intra-regional trade intensity and intra-industry trade. The complementarity of functional and institutional integration in East Asia remains to be observed and should certainly not be understated.

To analyse the region is to see clearly how functional integration, which is the result of economic dynamism enhanced by globalization and a certain degree of cultural commonality, is driving regional economic integration with no need for any formal institutional mechanism to augment or pool the sovereignty of the countries involved. Yet deeper institutionalization of economic cooperation and integration at the regional level is inevitable and necessary if countries wish to make processes 


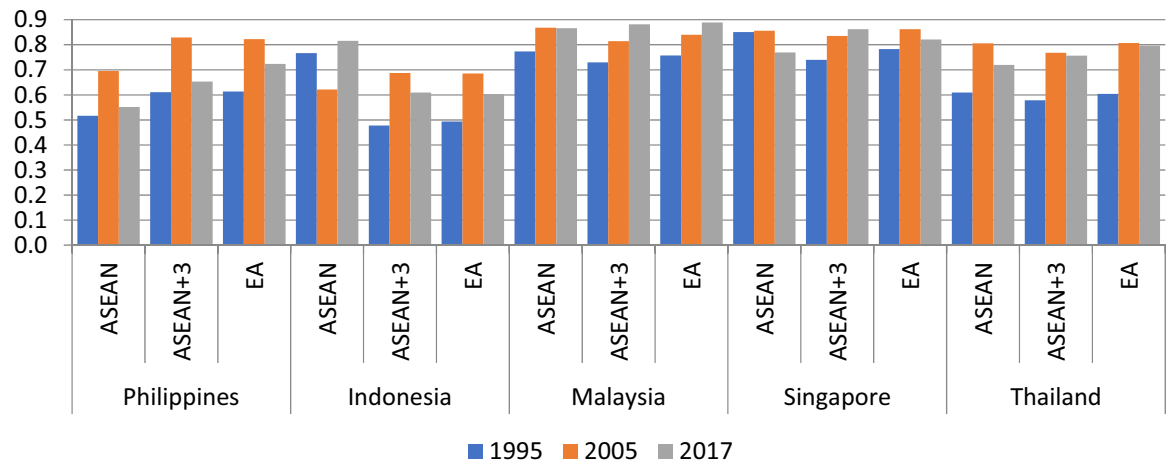

Fig. 8 Grubel-Lloyd intra-industry trade indexes: ASEAN-5 in respect of ASEAN, ASEAN +3 and East Asia in 1995, 2005, 2017. Source: Author's own calculations based on UNCTAD Database (2019)

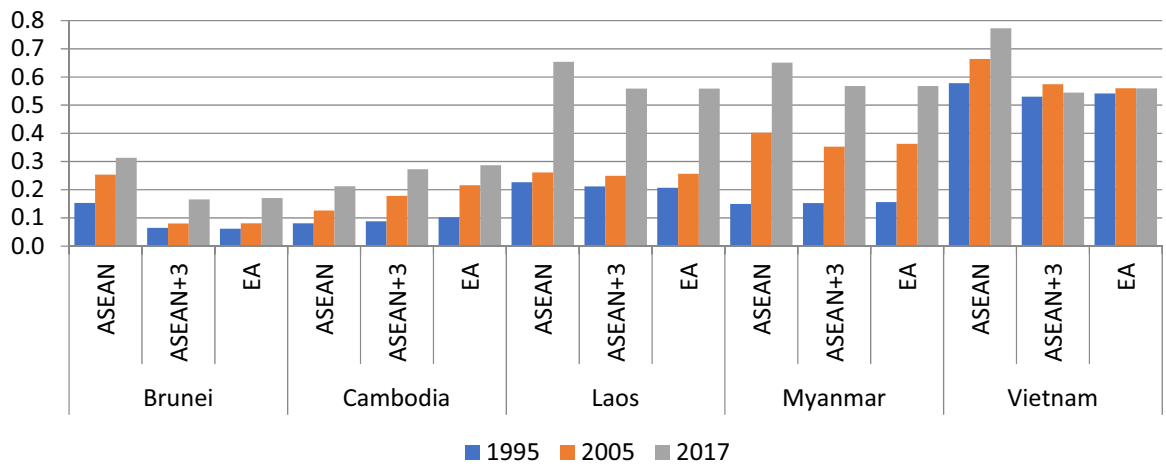

Fig. 9 Grubel-Lloyd intra-industry trade indexes: ASEAN-BCMLV in respect of ASEAN, ASEAN + 3 and East Asia in 1995, 2005, 2017. Source: Author's own calculations based on UNCTAD Database (2019)

more efficient. It is also remarkable to point out that growing economic interdependency continuously provides a credible foundation for the institutional integration in East Asia.

\section{Confucianism: norms and values in the context of cooperation and integration of societies}

Given its introduction as a mean of spreading the political ideology of the ruling classes among the people, Confucianism is not regarded as a religion but rather as a philosophy, a political ideology, a system of knowledge and an ethical framework for daily life (Kim and Sohn 2014, p. 156). Though social norms and political ideology have been shaped by Confucian values to varying degrees in East Asian nations, they have nevertheless had a profound impact on the East Asian cultural circle. 
The origin of Confucianism lies with Confucius (c. 551 BC to c. 479 BC) who was born in the ancient state of $\mathrm{Lu}$, which today is in China's Shandong province (Ames and Rosemont 1999, p. 2). The chief elements of Confucius's thought, which originated in the Spring and Autumn Period (approximately 500 B.C.) in ancient China, are the five cardinal relationships ( $w u$ lun), the five virtues ( $w u$ chang), and the golden mean (zhong yong). According to Confucius, society should be based on five dependencies and mutual obligations, which are known as the five cardinal relationships (wu lun) of monarch-subjects, parents-offspring, husbands-wives, friendsfriends and older brother-younger brother. Hence:

- Goodness of the prince-loyalty of the subject

- Father's love—son's attachment

- The kindness of the elderly - the respect of the young

- Justice of the husband-obedience of the wife

- Loyalty of a friend-reciprocity of a friend

According to Mencius (c. 371 BC to c. 289 BC) the basic principles of interpersonal communication are found in the courtesy between monarch and subjects, the blood relationship between parents and offspring, the love and division of labour between husband and wife and in trust among friends (Mencius 2010, after Ma et al. 2016, p. 32).

The five virtues (wu chang) stand for benevolence (ren), righteousness (yi), courtesy (li), wisdom (zhi) and trust (xin) (Ma et al. 2016, p. 41). 'Benevolence' may be interpreted as meaning kindness, 'righteousness' as dealing with problems properly, 'courtesy' as following the normal guidelines of interpersonal relationships, 'wisdom' as telling right from wrong and 'trust' as both honesty and trust (ibidem).

The fundamental and conceptual thought of Confucianism remains to be ren (humanity, humaneness, goodness, benevolence or love), as a central value of the philosophy, which is further the notion of traditional values such as a political ideology based on morality and the virtues of loyalty and filial piety (Kim and Sohn 2014 , p. 157). When applied to parents ren can be translated as filial piety, when applied to siblings it can be understood as fraternity, when applied to friends it can be interpreted as trust, when applied to devotion to others, society and the nation it can be translated as loyalty, and when applied to the principle of 'politics for the people' it can best be grasped as moral governance (Kim and Sohn 2014, pp. 157-158). Understood in this way, ren serves to reinforce family ties and maintain social and national solidarity. It is also understood as an ideal level of self-mind cultivation that is demonstrated by loving others and practicing moral virtue (ibidem).

The thought of the golden mean (zhong yong) refers to thinking and behaviour that is moderate and reasonable and so maintains harmonious relationships. Scholars have identified two principles that play a central role in the Confucian value system: ren and zhong yong (Chung et al. 1989, pp. 311-312). The principle of ren, which is synonymous with ideal humanity, reflects the ideal of the human pursuit of perfection, while the principle of zhong yong, which has a metaphysical character, refers to the balance between good and evil, harmony and disorder and truth and lies (See Fig. 11). 


\section{CONFUCIANISM}

\begin{tabular}{|c|c|c|}
\hline VALUES & NORMS & PRACTICES \\
\hline $\begin{array}{l}\text { Humanity } \\
\text { Benevolence } \\
\text { Harmony } \\
\text { Paternalism } \\
\text { Collectivism } \\
\text { Familism } \\
\text { Personalism }\end{array}$ & $\begin{array}{l}\text { Harmony } \\
\text { Trust } \\
\text { Loyalty } \\
\text { Fraternity } \\
\text { Moral } \\
\text { governance/morality } \\
\text {-based political } \\
\text { ideology } \\
\text { Filial piety }\end{array}$ & $\begin{array}{l}\text { Permanent search for } \\
\text { excellence/perfection } \\
\text { Centralized decision } \\
\text { making } \\
\text { Authoritarian } \\
\text { leadership } \\
\text { Collective attitudes } \\
\text { Familial } \\
\text { interrelationship } \\
\text { Serious attitude and } \\
\text { devotion to work } \\
\text { Respect for education } \\
\text { Savings and investments } \\
\text { Simple, ascetic life } \\
\text { Attention to detail } \\
\text { Diligence } \\
\text { Discipline }\end{array}$ \\
\hline
\end{tabular}

Fig. 10 Confucianism: operationalization of the construct. Source: Author's own elaboration

In social practice and in everyday life, Confucian followers feel the contradictions and tensions between reality as it is and reality as it should be, yet these pressures can be avoided and dissolved if people commit to continuous improvement, which is the bedrock of Confucianism. In this way the point of the Confucian ethical imperative is not to complete a project of improvement but to apply earthly discipline and hard work, rather than prayer and meditation, to approach the ideal of humanism (ren) and balance (zhong yong) (Nawrot 2008, p. 126). The practices resulting from the attitudes, values and norms of Confucianism develop as a consequence of tensions between the real and ideal state of the world and the impulse to release those tensions. The tenets of Confucianism are consistent with the spirit of capitalism and conducive to economic growth and development and are therefore expressed at the microeconomic and macroeconomic levels. Their role in economic development is discussed in the next section of the paper (compare Figs. 10, 11).

The values, norms and practices of Confucianism have been identified in an attempt to operationalize that body of thought in terms of values, norms and practices (see Fig. 10). At this point it is important to point out after Yao (2017, p. 1) that conceptualization is a highly intellectual activity requiring creativity and originality. Yet ideas, once they have been conceptualized, should not be treated as fixed, unchangeable and everlasting. They have always been subject to reinterpretation and reconceptualization, which means restructuring and redefining the meaning and value of an idea that has been structured and defined before (see Yao 2017, p. 1). The operationalization of Confucianism presented here should be received in this spirit and interpreted as flexible, changeable and open to further creative discussion and interpretation. 


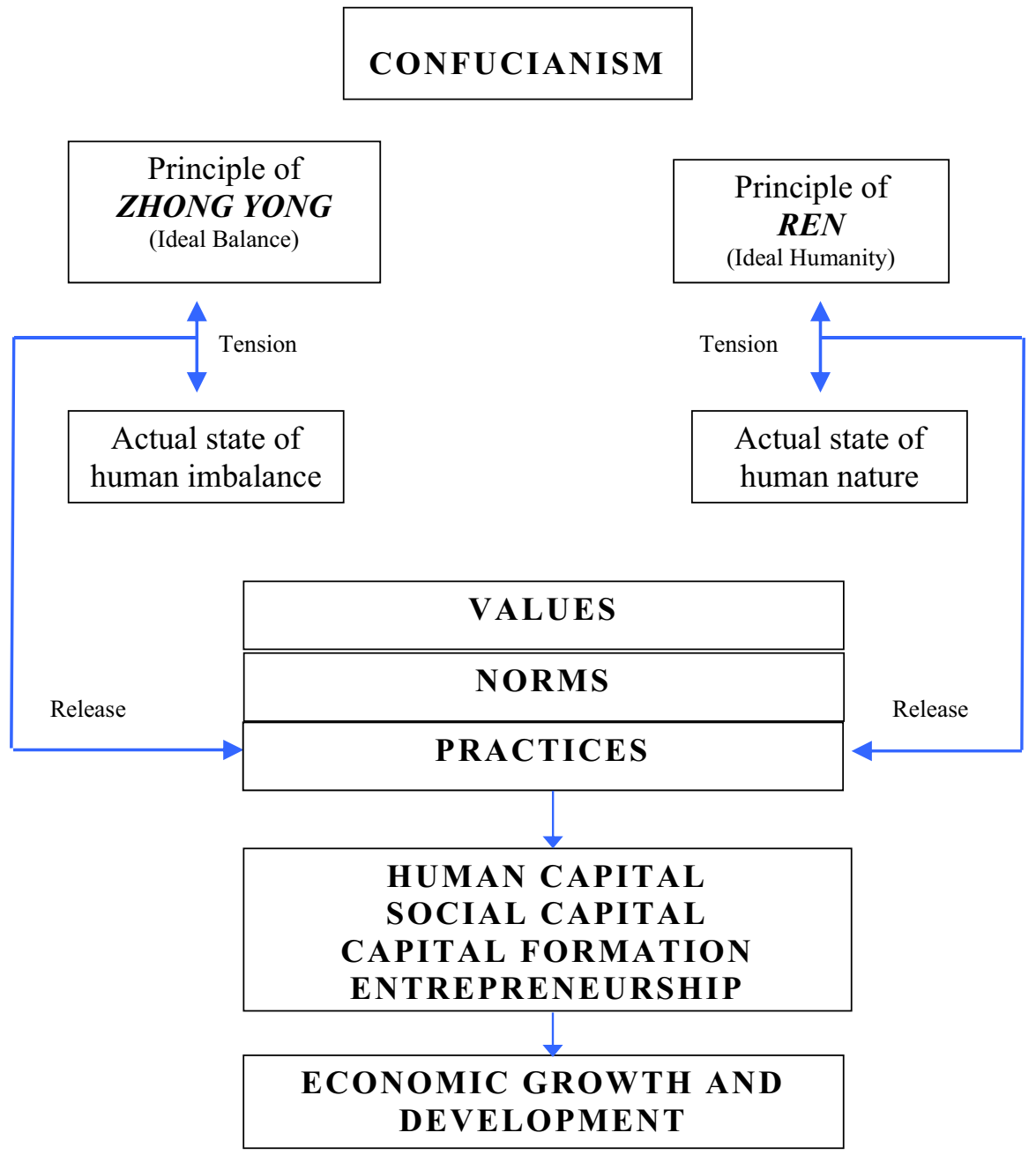

Fig. 11 The relationships between Confucianism and East Asian economic dynamism. Source: Author's own elaboration

\section{Confucianism as an element of the cultural system in East Asian economic development}

In the context of informal institutions, the cultural aspect has an undoubted significance in the debate on economic development, which received new impetus when North (1990) postulated that the key to understanding the influence of the past on the present and future is culture. Historically, Western standards of life, consumption, and political and social values have often been perceived as the chief determinants of progress and prosperity. It has even been argued that traditional thinking should be rejected in developing countries (Myrdal 1968, pp. 56-57). Cultural 
transformation was to be a prerequisite for modernization that would prepare a society for adopting a market economy and democracy. And, indeed, quite a number of scholars have concluded that progress in developing countries is not possible without radical cultural change (Schech and Haggis 2000, p. 10).

Experience gathered from the impressive economic growth and development of East Asian countries has prompted revision of the causes of developmental trajectories and the options for overcoming developmental obstacles. When attempting to explain the success of the Asian tigers, scholars and practitioners, and in particular those from the Asian cultural circle, have argued that cultural factors are the main catalysts of rapid capitalist development and that they determine economic success (Nawrot 2008, p. 125). They also began to refer to traits derived from Asian culture that were largely formed by Confucianism. The following features of East Asian societies may be of importance to economic development (Schech and Haggis 2000, p. 41; Chung et al. 1989, p. 312; Haliżak 1999, p. 87):

- Human relations and social harmony based on familism

- The central role of the family and family values

- Recognition of, and respect for, authority; powerful identification with the organization

- Rights of the individual subordinated to the general good: collectivism rather than individualism

- Thrift

- Hard work and diligence

- Self-discipline

- Emphasis on, and appreciation of, education

The example of the East Asian economies suggests that modernization and progress are possible without absolute submission to Western practices and values, and that indigenous cultural values and national identity can be preserved. It should be noted that the cultural conditions in East Asian countries resulting from Confucianism have influenced the formation of behaviours and their associated dispositions, and that, in turn, these behaviours have had a positive influence on the quality of human capital and so stimulated economic growth and development (See Fig. 11). Worth emphasising in this respect after Starzyk (2001, p. 16) are propensity to save and the value paced on education, which are accompanied by a readiness to make sacrifices and openness to foreign intellectual achievements.

Some scholars have, however, pointed out that Western capitalism in its early days was also based on family ties, but that, over time they came to be regarded as less valuable because of greater competition and the increasing size of businesses. As capitalism in East Asia has expanded, concerns have been raised about the erosion of familism or the general good, which are not necessarily values supported by production orientation, consumerism or an increase in the standard of living. The view has also been expressed that, in an era of liberalization and globalization, the Confucian ethic limits individual initiative and can obstruct economic growth and development because it requires subordination to tradition and power and often leads to conformist behaviour. It is unsurprising, 
therefore, that while the region's politicians seek to benefit from West-facing economic policies, they also want to avoid overshadowing their own culture when developing in this way (Nawrot 2008, p. 127).

According to Edward Haliżak (1999, p. 86), though, we should remember when assessing the impact of Confucianism on economic development that its interpretation has undergone significant changes depending on the social functions it is required to perform. We must therefore assume that Confucianism now is different from Confucianism two thousand years ago or two hundred years ago. Furthermore, in the sense that it regulates economic activity by teaching moderation, the role of Confucianism in economic development could be related to the Confucian philosophies of education and politics. Through tenets such as 'discipline yourself and take care of others' and 'put into practice what you know', Confucianism has to some extent harmonised ethical norms with economic attitudes. As Kim and Sohn (2014, p. 159) have emphasised, the combination of Confucian thought with a people-centred political ideology has served as the cultural ethos for the effective governance and stable economic development of East Asian economies since the 1960s.

Promoting Confucianism has a role to play in building both financial capital itself and human and social capital in the region. The formation of financial capital depends on the savings rate of nations, which in turn depends on people holding values such as asceticism, thrift and frugality. Further very important values that enhance economic growth and development, and at the same time construct social capital, are mutual trust, social trust, social ethics and education. There is little doubt that the economic performance of East Asian countries has been influenced by regional social and human capital resulting from Confucian values. To continue to promote and spread them cannot but lead to the further accumulation of social and human capital in the region (compare Figs. 10, 11).

A number of scholars have written of the importance of the ethical values of Confucianism as a shield against the inhumane and immoral aspects of the market system (Kim and Sohn 2014, p. 164). They assert that Confucian ethical values can prevent the corruption that capitalism entails and sustain a market economy. In this view, Confucian self-discipline is needed to mitigate the degradation of morals and the individualism of a post-industrial society that sanctions unlimited individual desire and competition. Furthermore, the traditional Confucian values of humanity, righteousness, moderation of attitude, loyalty, and filial piety can serve as an educational compass for repairing the ethical norms the market damages (ibidem, p. 165). As Kim and Sohn contend (2014, p. 165), Confucian economic community means applying Confucian moral ethics to market-oriented economic integration. This brand of economic integration can help protect the market economy from moral corruption and support sustainable development. In this way Confucian philosophy can compensate for the weaknesses of globalization, meet the cultural needs of a knowledge-based society and promote environmentally-friendly economic growth. The relationships between Confucianism and East Asian economic dynamism are shown in Fig. 11. 


\section{How significant are Confucian values for cooperation and integration in East Asia?}

The main research question we attempt to answer here is whether Confucianism can serve as a source of common regional values and regional identity in East Asia? In other words, how significant are Confucian values in the economic integration of East Asia? Regional identity is understood and defined as a common social and cultural foundation that promotes mutual trust and unity among the region's countries.

The key assumption made is that the necessary condition for recognizing a regional cultural system is the cultural similarity of the countries involved in economic integration, which can act as a background, pillar and/or catalyst for economic integration. In this way, common regional values can result from cultural similarities. Regional common values resulted from cultural similarity and commonality can form a central engine to consolidate the member countries into an integrated economic community. It can be stated in general terms, without reference to a specific region of the globe, that culture or cultural system is a necessary condition for economic integration at large.

We adopt here the concept of Kleer $(2013,2016)$ assuming that a cultural system consist of following factors: language, tradition, history, religion, a society's attitude to the state and the ruling elite's attitude to society. We further apply extension of the concept by one more element, namely the attitude to the role of women in the society (Nawrot 2019, p. 19). The above identified factors form a specific hexagon of different elements interacting within the boundaries of identified system, which in this paper refer to the region of East Asia. We further examine here only one element of the cultural system-Confucianism-which belongs to the category of religion.

With this conceptual platform in place, it is possible to ask two penetrating questions: To what extent does Confucianism provide a cultural commonality for East Asian countries? A fortiori, to what extent does Confucianism provide a cultural commonality for East Asian countries that is capable of generating common regional values (East Asian values) derived from Confucian values?

Based on research, five groups of economies in East Asia were identified according to commonality in Confucian values:

- China, Hong Kong, Taiwan

- Japan, South Korea, Vietnam

- Singapore, Malaysia, Thailand

- Indonesia, Brunei Darussalam, Philippines

- Cambodia, Laos, Myanmar

China, Hong Kong and Taiwan were detected on the ground of the higher similarities of culture, not only in religious and ideological dimension, but also because of their common language, tradition and history. The second group of Japan, South Korea and Vietnam were identified as second set of commonalities 
in the region resulted in presence of Confucianism followed by similarities in other cultural features like related norms and behaviours, their history and their geographical proximity to China. Singapore, Malaysia, and to some extent Thailand, have the most populous Chinese diaspora, and so are more exposed to Confucian culture. Their societies therefore share a fairly strong similarity and commonality in their Confucianism and Asian values. The weakest commonality of Confucian cultural values was detected in Cambodia, Laos, Myanmar, Indonesia, Brunei Darussalam and the Philippines, which is perhaps best analysed as two groups of three. For the first, it can be said that Islam is the dominant religion in Brunei Darussalam, that Indonesia is the world's biggest Muslim country and that the Philippines is the largest Christian country in Asia. It would seem that the grounds for common values are far weaker here than in Cambodia, Laos and Myanmar, whose shared Buddhism places them closer to the regional values of the majority of countries in East Asia. It is important to be clear that when compared to the rest of East Asia, the Northeast Asian countries are more integrated and culturally similar, which is partly the result of inherited cultural values stemming from Confucianism.

In search of the influence of Confucianism on the economic integration of East Asia, two dimensions need to be recognized, namely institutional and functional integration. Consequently we need to explore the significance of Confucian values in the functional economic integration and institutional integration of East Asia. Particular East Asian countries share common values derived from Confucianism to a different extend. The same refers to their varied experiences of industrialization, modernization and developmental processes, as well as history. Yet they remain a very important condition of functional and institutional economic integration in the region.

Cultural identity and, taking the example of the East Asian countries, Asian identities and resulting Asian values, can be defined as a common cultural and social consciousness that promotes mutual cooperation and integration. This body of thought rests on Confucian values which have shaped the region's social capital and contributed to the economic development of its economies. This holds true whether we are speaking of moral awareness, the greater commitment of politicians to the people and the emphasis on education, or whether we are recalling the virtues of thrift, diligence and self-discipline-all of which promise an orderly society and orderly behaviour.

The great enthusiasm for, and emphasis on, education and thrift underpinned the formation of human capital and brought economic development and swifter growth in the Confucian countries-mainly Japan, Korea, Taiwan, Hong Kong and Singapore where Confucian values were found to be particularly strong. This supports the argument that Confucianism and capitalism are complementary and likely to give rise to economic growth and development. Some scholars further argue that the government-driven economic development of East Asian countries in the 1970s and 1980s was partially assisted by their Confucian cultural heritage. In this understanding, the government's Confucian sense of responsibility for the people was expressed in a people-centred public administration, so that the rulers were acting in harmony with the people's Confucian sense of loyalty to the nation. 
To a great degree, the dynamic economic growth and development of East Asian countries has led the region to self-discover a common identity. It can thus be argued that the emergence of the Asian values discourse was a response to the economic growth and development of the region and to the success of East Asian capitalism. The regionalization of the global economy provided additional background for the formation of Asian identity and Asian values. As Pieterse argues (1994), this discourse could be interpreted as the outcome of regionalization or of localization accompanying globalization. Dirlik (2004), meanwhile, construes the Asian values discourse as the re-emergence of nationality precipitated by globalization, and comprehends the resurrection of Confucianism as the outcome of the economic success of East Asia (after Kang 2004, p. 119). Interaction and influence can therefore be interpreted by putting culture and identity first or by putting economic integration first. In this way, culture and cultural identity has an impact on cooperation, integration and regionalization and/or cooperation, integration and regionalization influences the rediscovery and construction of an Asian identity. It might be added here that, though the influence of Confucianism on economic growth, development and East Asian capitalism has been studied extensively, few analyses have attempted to investigate how it could act as a platform for regional identity-building and so enhance regional cooperation and integration.

The main features of East Asia as a region, which this paper has mainly described in terms of its economic potential and the way cooperation and integration have evolved there, could be encapsulated as heterogeneity, tension, cooperation, competition and coordination, transformation and growth, and renewal. Li (2014, 2019) understands the Confucian conception of harmony to consist of the following elements: heterogeneity, tensions, coordination and cooperation, transformation and growth, and renewal. The resemblance is striking and recognizably, they form almost identical set of characteristics. At the same time, we can state that the process of integration - in different dimensions and at different levels - is the process of harmonization. Accordingly, integration-whether we perceive it as a state or as a condition-is an exemplification of harmony. As showed on the example of East Asia, and as European community building case makes clear, lack of harmony or threat to lose it, can act as a catalyst for integration. On the other hand, integration does enhance harmony and conclusively harmony certainly enables integration. Last but not least, we might venture to employ a slight modification of an inspiring term coined by Roger Ames and state that the effectiveness of integration depends on optimizing regional symbiosis (see Ames 2019). ${ }^{4}$

\footnotetext{
${ }^{4}$ The term 'optimizing regional symbiosis' is inspired by the concept of 'Optimizing Symbiosis' by Roger T. Ames.
} 


\section{Conclusions and recommendations}

This paper has striven to examine cultural commonality in East Asia based on Confucianism and its relation to economic cooperation and integration. It supports the conclusion that Confucianism has played a role in the economic growth and development of the region's countries. Despite this, however, there is still insufficient recognition of Confucian and Asian values as a foundation for constructing regional identity on which economic integration can be build and enhanced. This study has demonstrated that cultural similarity based on Confucianism has played a greater role in functional rather than institutional cooperation and integration, which is exemplified by production networks, intra-regional trade, intra-industry trade and sub-regional cooperation. Yet, as political and security threats were the very first catalysts of the integration processes in East Asia, followed by functional integration through the market forces, the institutionalization of the processes is inevitable and necessary to deepen the cooperation and integration, which can be further strengthen by building on a regional identity.

The regional cultural community and Confucianism were not recognized until the 1990s in discussions of East Asian regional economic integration. However, an appreciation of common cultural identity could offer new potential for constructing institutional economic integration in East Asia. In this way, cultural community based on Confucianism can serve as a pillar of regional identity and values and as a necessary condition of the consolidation and integration of East Asian countries in a single economic community. Furthermore, cultural community and regional identity based on Confucianism seems more likely to succeed than any other aspect of the cultural system. In that respect European integration can offer some lessons for East Asian economic cooperation and integration:

- Recognizing the historical and cultural commonality of the region's countries

- Establishing a regional identity based on Confucianism as a common element of national cultural systems

- Developing unity in diversity as a common regional policy

This cannot be done, though, without the strong will and commitment of all of the countries from the region of East Asia.

Confucianism culture and cultural commonality resulted in shared values can serve as a key factor in the integration of East Asia and in its institutional dimension. Thus, the Confucian cultural commonality can provide an opportunity for East Asian countries to develop regional identity and enhance regional identity building resulting in more economically integrated region. The success of this endeavour requires functional integration, institutional integration and a regional identity based on the cultural system and on cultural identity. Institutional integration in the region will be further advanced if regional integration can be endowed with socio-cultural solidarity. Further implications could include:

- Sharing a common system of recognition in the region 
- Preventing imperialism on the part of the hegemonic powers

- Establishing regional solidarity and cooperation

Recognizing, promoting and elaborating East Asian values can act as a counterweight to Western values, including those of the European and American cultural communities. However a cultural identity based on Confucianism has not yet been recognized regionally or appreciated as a potential platform on which cooperation and integration can be built. If Confucianism and Asian values are to be a foundation for cooperation and integration in East Asia, and if they are to be a source of regional identity in the region, they must be reidentified, revalued and redefined in the current economic reality of the market system and ongoing processes of globalization and regionalization. If so, they can function as a set of cultural values common to East Asian countries.

Acknowledgements The paper is the result of the research project "East Asia in regional cooperation and governance" financed by the National Science Centre, Poland (decision no. DEC-2013/09/B/ HS4/01147).

Open Access This article is licensed under a Creative Commons Attribution 4.0 International License, which permits use, sharing, adaptation, distribution and reproduction in any medium or format, as long as you give appropriate credit to the original author(s) and the source, provide a link to the Creative Commons licence, and indicate if changes were made. The images or other third party material in this article are included in the article's Creative Commons licence, unless indicated otherwise in a credit line to the material. If material is not included in the article's Creative Commons licence and your intended use is not permitted by statutory regulation or exceeds the permitted use, you will need to obtain permission directly from the copyright holder. To view a copy of this licence, visit http://creativecommons.org/licen ses/by/4.0/.

\section{References}

ADB. 2010. Institutions for regional integration. Toward an Asian economic community. Manila: Asian Development Bank.

ADB. 2014. Key indicators for Asia and the Pacific 2014. Manila: Asian Development Bank.

ADB. 2018. Key indicators for Asia and the Pacific 2018. Manila: Asian Development Bank.

Ames, R.T. 2019. Confucian harmony (he 和) as an optimizing symbiosis. 2019 Confucian conference. Confucianism and world disharmony: The quest for harmony in difference, 28-31 August 2019. Gold Coast: Bond University.

Ames, R.T., and H. Rosemont Jr. 1999. The Analects of Confucius: A philosophical translation. New York: Ballantine Books.

Anderson, B. 2006. Imagined communities. Reflections on the origin and spread of nationalism. LondonNew York: Verso.

ARIC. 2018. ARIC database 2018. Asian Development Bank. https://www.adb.org/. Accessed 1 May 2018.

ARIC. 2019. ARIC database 2019. Asian Development Bank. https://www.adb.org/. Accessed 1 Aug 2019.

Baldwin, R., and P. Thornton (eds.). 2008. Multilateralising regionalism ideas for WTO action plan on regionalism. CEPR, The Graduate Institute: London-Geneva.

Banga, R. 2013. Measuring value in global value chains. Background Paper Np. RVC-8, UNCTAD, May. Buckley, R.P., HuR Weixing, and D.W. Arner (eds.). 2011. East Asian economic integration. Chelthenham: Edward Elgar. 
Cho, Myung-Rae. 1997. Transborder networks and geogovernance: A comparison of the Great South China region and the Bohai Rim region: 1-28. Paper presented at the International Conference of Regional Studies Association held in Frankfurt, Germany, Sept. 20-23, 1997.

Chung, ChH, J.M. Shepard, and M.J. Dollinger. 1989. Max Weber revisited: Some lessons from East Asian capitalistic development. Asia Pacific Journal of Management 6 (2): 307-321.

Dirlik, A. 2004. Does culture oppose history?: 'West' in East Asia's quest of identity”. After Kang Jung In 2004 The cultural identity of East Asia in the age of globalization: Westernism and Asian values. The Korean Journal of International Relations 44 (5): 109-133.

Frost, E.L. 2008. Asia's new regionalism. London: Lynne Riener.

Fujita, M., I. Kuroiwa, and S. Kumagai (eds.). 2011. The Economics of East Asian integration. A comprehensive introduction to regional issues. Chelthenham: Edward Elgar.

Grabowski, M. 2015. Rywalizacja czy integracja? Procesy i organizacje integracyjne $w$ regionie Azji $i$ Pacyfiku na przełomie XX $i$ XXI wieku. Kraków: Księgarnia Akademicka.

Haliżak, E. 1999. Stosunki międzynarodowe w regionie Azji i Pacyfiku. Warszawa: Wydawnictwo Naukowe Scholar.

Haliżak, E. 2006. Wspólnota Pacyfiku a Wspólnota Azjatycka. Żurawia Papers 8. Warszawa: Instytut Stosunków Międzynarodowych UW.

Hausmann, R. 2019. 'Cutting edge of development thinking'. Executive Education Program. Cambridge: Harvard Kennedy School.

IMF. 2013. World economic outlook Hopes, realities, risks. Washington DC: International Monetary Fund.

Kang, Jung In. 2004. The cultural identity of East Asia in the age of globalization: Westernism and Asian values. The Korean Journal of International Relations 44 (5): 109-133.

Khoman, T. 1992. ASEAN conception and evolution. The ASEAN reader. Singapore: Institute of Southeast Asian Studies.

Kim, H., and B. Sohn. 2014. Economic integration vs. conflicts in Northeast Asia-A role of Confucianism. Asian Social Science 10 (13): 155-168.

Kim, Kyung-il. 1998. East Asia and the world system theory. Journal of Spiritual Culture Studies 21 (1): $27-45$.

Kleer, J. 2013. Kulturowe uwarunkowania modernizacji. Droga do spójności społeczno-ekonomicznej. Warszawa: PWN.

Kleer, J. 2016. Związki między myśleniem strategicznym a wielokulturowością. In Dokqd zmierza Europa: Państwo-Gospodarka-Społeczeństwo-Finanse, ed. J. Kleer, P. Szukalski \& K. Prandecki, 208-232. Warszawa: Polska Akademia Nauk, Komitet Prognoz, Polska 2000 Plus.

Kumar, N., R. Sen, and M. Asher (eds.). 2006. India-ASEAN economic relations. Meeting the challenges of globalization. Singapore-New Delhi: Institute of Southeast Asian Studies/Research and Information System for Developing Countries.

Li, Chenyang. 2014. The Confucian philosophy of harmony. London and New York: Routledge.

Li, Chenyang. 2019. Harmony, domination, and freedom. In 2019 Confucian Conference. Confucianism and World Disharmony: The Quest for Harmony in Difference, 28-31 August 2019. Gold Coast: Bond University.

Ma, W., Feng, R., Hu, R., Xi, J., Fox, E., \& Ding, X. 2016. Toward the theoretical constructs of East Asian cultural psychology. In Unity, diversity and culture. Proceedings from the 22nd Congress of the international association for cross-cultural psychology, ed. C. Roland-Lévy, P. Denoux, B. Voyer, P. Boski, W. K. Gabrenya Jr. https://scholarworks.gvsu.edu/iaccp_papers/228. Accessed 1 Aug 2019.

Myrdal, G. 1968. Asian drama: The inquiry into the poverty of nations. London: Twentieth Century Fund.

Nawrot, K.A. 2007. Integracja regionalna z perspektywy Azji Południowo-Wschodniej i Ameryki Łacińskiej. In Ameryka Łacińska $w$ regionie Azji i Pacyfiku, ed. M.F. Gawrycki, 361-382. Warszawa: Wydawnictwo Adam Marszałek.

Nawrot, K.A. 2008. Determinanty rozwoju gospodarczego państw ASEAN. Warszawa: Wydawnictwo Naukowe Scholar.

Nawrot, K.A. 2012. Current challenges to the changing pattern of East Asian Cooperation and Governance-European Perspective. Actual Problems of Economics 2 (7): 15-23.

Nawrot, K.A. (2013). Kryzys światowego system finansowego a rynki azjatyckie. In Kryzysy systemowe, ed. E. Mączyńska, J.J. Michałek, J. Niżnik, 279-293. Warszawa: Polska Akademia Nauk, Komitet Prognoz, Polska 2000 Plus. 
Nawrot, K.A. 2014. Kraje rozwijajace się we wspótczesnej gospodarce światowej. Przyczynek do ekonomii rozwoju. Warszawa: Wydawnictwo Naukowe Scholar.

Nawrot, K.A. 2016. Industrializacja gospodarek Azji Wschodniej w latach 1985-2015. In Region Azji $i$ Pacyfiku $w$ latach 1985-2015. Ciagłość i zmiana $w$ regionalnym systemie międzynarodowym, ed. A. Jarczewska, J. Zajączkowski, 353-374. Warszawa: Wydawnictwo Naukowe Scholar.

Nawrot, K.A. 2018. Trade for economic development in Sub-Saharan (Eastern) Africa: A critical commentary. In Developmental state and millennium development goals-Country experiences, ed. K. Roy and S. Kar, 147-167. Singapore: World Scientific.

Nawrot, K.A. 2019. Culture system and development: A theoretical perspective and conceptual framework for further research. In A discourse on economic development. Readings in World Development, ed. K. Roy and C. Clark, 17-28. New York: Nova Science Publishers.

North, D.C. 1990. Institutions, institutional change and economic performance. Cambridge: Cambridge University Press.

Park, J., T.J. Pempel, and H. Kim (eds.). 2011. Regionalism, economic integration and security in Asia. A political economy approach. Cheltenham: Edward Elgar.

Pieterse, N.J. 1994. Globalization as hybridization. International Sociology 9 (2): 161-184.

Rajaratnam, S. 1992. ASEAN: The way ahead. The ASEAN Reader. Singapore: Institute of Southeast Asian Studies.

Schech, S., and J. Haggis. 2000. Culture and development. A critical introduction. Oxford: Blackwell Publishers.

Singh, D., and T.M.M. Than (eds.). 2008. Southeast Asian Affairs 2008. Singapore: Institute of Southeast Asian Studies.

Starzyk, K. (ed.). 2001. Zagraniczne inwestycje bezpośrednie w gospodarkach Azji i Pacyfiku. Warszawa: Wydawnictwo Naukowe Semper.

$\mathrm{Su}, \mathrm{H}$. 2010. The EU's Taiwan Policy in a new context, issues and studies. A Social Science Quarterly on China, Taiwan, and East Asian Affairs 46 (1): 1-53.

Tellis, A.J., T. Tanner, and J. Keough (eds.). 2011. Asia responds to its rising powers China and India. Strategic Asia 2011-2012. The National Bureau of Asian Research: Seattle-Washington D.C.

UNCTAD. 2019. UNCTAD database 2019. https://www.unctad.org/. Accessed 2 June 2019.

UNDP. 2018. Human development indices and indicators. 2018 statistical update. New York: Oxford University Press, United Nations Development Programme.

Welfens, P.J.J., F. Knipping, S. Chirathivat, and C. Ryan (eds.). 2006. Integration in Asia and Europe. Historical dynamics, political issues, and economic perspectives. Berlin-Heidelberg-New York: Springer.

World Bank. 2018. World bank database.

WTO. 2015. International trade statistics 2015. Geneva.

Wu, Chien-Huei. 2010. The ASEAN economic community under the ASEAN Charter; its external economic relations and disputes settlements mechanisms. In European yearbook of international economic law 2010, ed. C. Hermann and J.P. Terhechte, 331-357. Berlin-Heidelberg: Springer.

Yao, X. (ed.). 2017. Reconceptualizing Confucian philosophy in the 21st century. Singapore: Springer and Higher Education Press. 